\title{
Geochemical characterization and evaluation of groundwater suitability for domestic and agricultural utility in semi-arid region of Basara, Telangana State, South India
}

\author{
Narsimha Adimalla ${ }^{1}$ (D) . Sudarshan Venkatayogi ${ }^{1}$
}

Received: 12 August 2016 / Accepted: 16 February 2018 / Published online: 24 February 2018

(c) The Author(s) 2018. This article is an open access publication

\begin{abstract}
Hydrogeochemical investigations were carried out in semi-arid region of Basara to estimate the quality of groundwater for its suitability for domestic and agricultural purposes. For this region 34 groundwater samples were collected in different locations and analyzed for various ions, viz., $\mathrm{Na}^{+}, \mathrm{Ca}^{2+}, \mathrm{Mg}^{2+}, \mathrm{K}^{+}, \mathrm{Cl}^{-}, \mathrm{HCO}_{3}{ }^{-}, \mathrm{SO}_{4}{ }^{2-}, \mathrm{CO}_{3}{ }^{2-}, \mathrm{HCO}_{3}{ }^{-}, \mathrm{NO}_{3}{ }^{-}$and $\mathrm{F}^{-}$to assess the water chemistry with sodium absorption ratio, $\% \mathrm{Na}$, residual sodium carbonate, magnesium hazard. The nitrate and fluoride concentrations were above the maximum permissible limit, while calcium, sodium, potassium and chloride were found below the desirable limits in most of the groundwater samples. The Wilcox diagram illustrates that 59\% of the samples belong to excellent to good category, while the US Salinity Laboratory diagram indicates medium salinity/low sodium content in $64.70 \%$ of samples. In general, the geochemistry of groundwater in Basara region is influenced by the water rock processes through percolation and dissolution of rock forming minerals, while calculated values of saturation index for Anhydrite, Aragonite, Artinite, Brucite, Calcite, Fluorite, Gypsum, Dolomite and Magnesite of the groundwater samples were less than zero, indicating under-saturation. Chadha rectangular diagram for geochemical classification and hydrochemical processes of groundwater for Basara provinces indicates $50 \%$ of $\mathrm{Na}^{+}-\mathrm{Cl}^{-}, 29 \%$ of $\mathrm{Ca}^{2+}-\mathrm{Mg}^{2+}-\mathrm{Cl}^{-}$and $18 \%$ of the water samples concentrate in the category of $\mathrm{Na}^{+}-\mathrm{HCO}_{3}{ }^{-}$type.
\end{abstract}

Keywords Hydrochemistry $\cdot$ Groundwater quality $\cdot$ SAR $\cdot \% \mathrm{Na} \cdot \mathrm{RSC} \cdot$ Basara $\cdot$ South India

\section{Introduction}

In recent times, there has been a tremendous increase in demand for freshwater and water shortage in arid and semiarid regions due to population increase, urbanization, industrialization and intense agricultural activities in many parts of the world (Raju et al. 2011). Due to inadequate supply of surface waters, most of the places in India are depending mainly on groundwater resources for drinking and domestic, industrial, and irrigation uses. Hence, safe drinking water is a basic need of human development, health and well-being

Electronic supplementary material The online version of this article (https://doi.org/10.1007/s13201-018-0682-1) contains supplementary material, which is available to authorized users.

Narsimha Adimalla

adimallanarsimha@gmail.com

1 Department of Applied Geochemistry, University College of Science, Osmania University, Hyderabad 500 007, India and hence, an internationally accepted human right (WHO 2011). Moreover, water has been viewed as an infinite and bountiful resource; water today defines human, social and economic development. The alarming rate of population growth, evolving industrial society, advances in technology, and the existing trend of depletion of groundwater resource has raised some serious environmental problems. The quality of drinking water has increasingly been questioned from health point of view for many decades (Vinod et al. 2009). Hence, knowledge on hydrochemistry of freshwater is important to assess the quality of groundwater in especially rural areas that influences the suitability of groundwater for domestic, irrigation, and industrial needs. For this reason, groundwater is a very precious natural resource. The severity of environmental problems related to groundwater varies from place to place depending on the geology, hydrologic, climatic conditions and geochemical factors that influence. However, groundwater quality studies with reference to drinking and irrigation purposes in different regions have been carried out, viz., Anantapur (Gowd 2005), Tamil Nadu 
(Subramani et al. 2005), Uttarakhand (Jain et al. 2010), Punjab (Kumar et al. 2007), Sri Lanka (Nishanthiny et al. 2010), Iran (Aghazadeh and Mogaddam 2010; Narany et al. 2015), Nigeria (Ackah et al. 2011), and China (Zhang et al. 2012).

Groundwater in India accounts for about $80 \%$ of domestic water requirements and more than $45 \%$ of total agricultural water, irrigating 39 million hectares (Kumar et al. 2005). Groundwater is also the single largest and most productive source of water for irrigation in India (Kinzelbach et al. 2003). Mikayilov and Acar 1998 has concluded that the relationship between agricultural practices and groundwater pollution was established. Earlier studies have identified different types of groundwater pollution like geogenic or anthropogenic source, major ions, nitrogen pollutants, trace elements, agricultural pesticides, dissolution or weathering of the rocks and soil (Adimalla and Venkatayogi 2017; Narsimha and Sudarshan 2017a, b; Narsimha and Sudarshan 2013; Ding and Zhang 2002; Islam and Singhal 2004; Elhatip et al. 2003; Kara et al. 2004; Krishna and Govil 2004; Narsimha et al. 2013a; 2013b; McBride 2004; Guo et al. 2007).

The present study area is located in the southwestern part of the Adilabad district and forms part of the Survey of India toposheet $56 \mathrm{~F} / 13$. The area lies between the North latitudes $18^{\circ} 51^{\prime}$ and $18^{\circ} 59^{\prime}$ and East longitudes $77^{\circ}$ $54^{\prime}$ and $77^{\circ} 59^{\prime}$ (Fig. 1) covering an area of $186 \mathrm{~km}^{2}$. The study area covers main villages Basara, Mudhol, Melapur, Bederelli, Aljapur, Yamcha, Pedda Kirgul, Chinna Kirgul, Oni, Ruvi, Shetpalli, Bamangaon, Gannora, Vitholi, Vitholi Tanda and Karegaon. The Basara region occupied by Archaean crystalline rocks is represented by pink and gray granites. These granites are composed of quartz, feldspars has major minerals, biotite, fluorite and apatite as accessory minerals (Narsimha and Sudarshan 2017b). The mean daily minimum and maximum temperature is 15 and $29{ }^{\circ} \mathrm{C}$ during December and 28 and $46{ }^{\circ} \mathrm{C}$ during May. The normal annual rainfall in the district is $1157 \mathrm{~mm}$ (Narsimha and Sudarshan 2017b). The groundwater is the major source of water for domestic, drinking, and agricultural needs of the area. As yet, the geochemistry of groundwater and its appropriateness for drinking and agricultural purposes in the semi-arid region of Basara have not been studied in great detail. For this reason, a detailed hydrogeochemical study and classification of the groundwater was carried out to evaluate their suitability

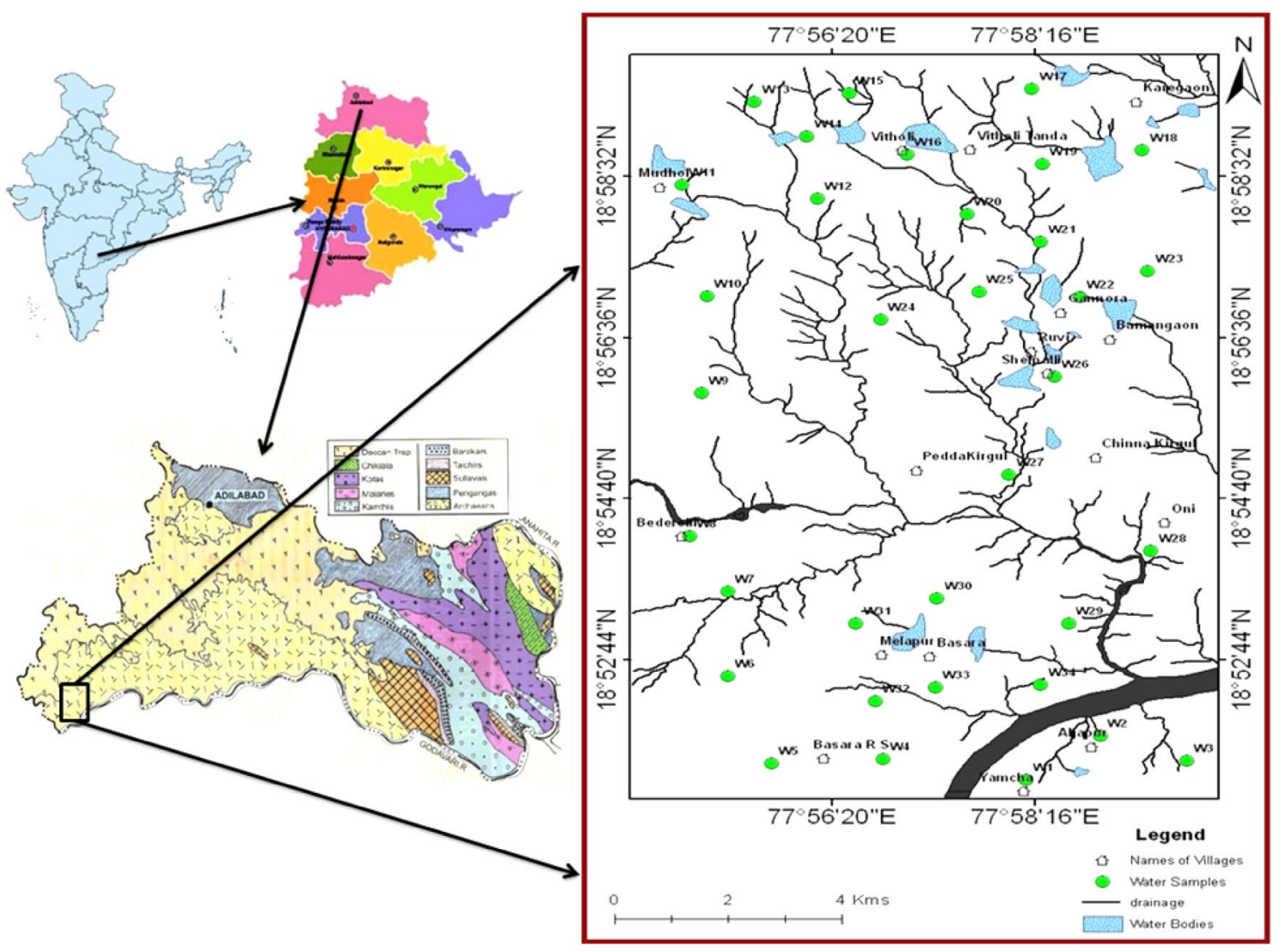

Fig. 1 Location map of the Basara area and its groundwater locations along with drainage pattern from Adilabad district, Telangana State, South India 
for various purposes, viz., domestic/drinking water and irrigation/agricultural purposes.

\section{Materials and methods}

Systematic groundwater sampling was carried out in 34 representative bore wells from the Basara region in Adilabad District to get the baseline information regarding its quality (Fig. 1). The entire study area has only bore wells ranging from 30 to $60 \mathrm{~m}$ depth. The samples were collected after $10 \mathrm{~min}$ of pumping and stored in polyethylene bottles. Immediately after sampling, $\mathrm{pH}$, electrical conductivity (EC), and total dissolved solids (TDS) were measured in the field itself. Other major parameters magnesium $\left(\mathrm{Mg}^{2+}\right)$, calcium $\left(\mathrm{Ca}^{2+}\right)$, sodium $\left(\mathrm{Na}^{+}\right)$, potassium $\left(\mathrm{K}^{+}\right)$, chloride $\left(\mathrm{Cl}^{-}\right)$, carbonate $\left(\mathrm{CO}_{3}{ }^{2-}\right)$, bicarbonate $\left(\mathrm{HCO}_{3}{ }^{-}\right)$, fluoride $\left(\mathrm{F}^{-}\right)$, nitrate $\left(\mathrm{NO}_{3}{ }^{-}\right)$and sulfate $\left(\mathrm{SO}_{4}{ }^{2-}\right)$ were analyzed according to the standard procedures described in standard methods for the examination of groundwater (APHA 1999; Table 1). The groundwater samples were collected and analysis was completed within $72 \mathrm{~h}$ in the Hydrogeochemical lab at Applied Geochemistry Department, Osmania University, Hyderabad. In addition to this, US Salinity Laboratory diagram, Chadha diagram and Wilcox diagram were employed to classify and determine the suitability of groundwater for irrigation by correlating sodium absorption ratio/electrical conductivity and percent sodium/electrical conductivity, respectively (Table 1). Eventually saturation indices for Anhydrite, Aragonite, Artinite, Brucite, Calcite, Fluorite, Gypsum,

Table 1 Instrumental, titrimetric and calculation methods were used for chemical analysis of groundwater samples from Basara region, Telangana State

\begin{tabular}{|c|c|c|c|c|c|}
\hline Parameters & Characteristics & Analytical method & Reagents & Unit & References \\
\hline \multirow[t]{4}{*}{ General } & $\mathrm{pH}$ & $\mathrm{pH} / \mathrm{EC} / \mathrm{TDS}$ meter & $\mathrm{pH} 4,7$ and 9.2 & - & APHA (1999) \\
\hline & Electrical conductivity & $\mathrm{pH} / \mathrm{EC} / \mathrm{TDS}$ meter & Potassium chloride & $\mu \mathrm{S} / \mathrm{cm}$ & APHA (1999) \\
\hline & Total dissolved solids (TDS) & Calculation & EC X $(0.55-0.75)$ & $\mathrm{mg} / \mathrm{L}$ & Hem (1991) \\
\hline & Total hardness (as $\mathrm{CaCO}_{3}$ ) & EDTA titrimetric & $\begin{array}{l}\text { EDTA, ammonia buffer } \\
\text { and Eriochrome Black-T } \\
\text { (EBT) indicator }\end{array}$ & $\mathrm{mg} / \mathrm{L}$ & APHA (1999) \\
\hline \multirow[t]{4}{*}{ Major cations } & Calcium $\left(\right.$ as $\left.\mathrm{Ca}^{2+}\right)$ & EDTA titrimetric & $\begin{array}{l}\text { EDTA, sodium hydroxide } \\
\text { and murexide }\end{array}$ & $\mathrm{mg} / \mathrm{L}$ & APHA (1999) \\
\hline & Magnesium (as $\mathrm{Mg}^{2+}$ ) & Calculation & $\begin{aligned} \mathrm{MgH} & =\mathrm{TH}-\mathrm{CaH} ; \\
\mathrm{Mg} & =\mathrm{MgH} \text { X Eq.Wt of } \\
\mathrm{Mg} & \times \text { Normality of EDTA }\end{aligned}$ & $\mathrm{mg} / \mathrm{L}$ & APHA (1999) \\
\hline & Sodium $\left(\right.$ as $\left.\mathrm{Na}^{+}\right)$ & Flame photometric & $\begin{array}{l}\text { Sodium chloride }(\mathrm{NaCl}) \\
\text { and } \mathrm{KCl}\end{array}$ & $\mathrm{mg} / \mathrm{L}$ & APHA (1999) \\
\hline & Potassium (as $\mathrm{K}^{+}$) & Flame photometric & $\mathrm{NaCl}$ and $\mathrm{KCl}$ & $\mathrm{mg} / \mathrm{L}$ & APHA (1999) \\
\hline \multirow[t]{5}{*}{ Major anions } & Bicarbonates $\left(\mathrm{HCO}_{3}^{-}\right)$ & Titrimetric & $\begin{array}{l}\text { Hydrosulfuric acid }\left(\mathrm{H}_{2} \mathrm{SO}_{4}\right) \text {, } \\
\text { phenolphthalein and } \\
\text { methyl orange }\end{array}$ & $\mathrm{mg} / \mathrm{L}$ & APHA (1999) \\
\hline & Chloride $\left(\mathrm{Cl}^{-}\right)$ & Titrimetric & $\begin{array}{l}\text { Silver nitrate }\left(\mathrm{AgNO}_{3}\right) \\
\text { potassium chromate }\end{array}$ & $\mathrm{mg} / \mathrm{L}$ & APHA (1999) \\
\hline & Sulfates $\left(\mathrm{SO}_{4}{ }^{2-}\right)$ & $\begin{array}{l}\text { UV-visible spectropho- } \\
\text { tometer }\end{array}$ & $\begin{array}{l}\mathrm{HCl} \text {, ethyl alcohol, } \mathrm{NaCl}, \\
\text { barium chloride, sodium } \\
\text { sulfate }\end{array}$ & $\mathrm{mg} / \mathrm{L}$ & APHA (1999) \\
\hline & Nitrate $\left(\mathrm{NO}_{3}^{-}\right)$ & $\begin{array}{l}\text { UV-visible spectropho- } \\
\text { tometer }\end{array}$ & $\begin{array}{l}\text { Potassium nitrate (KNO3), } \\
\text { Phenol disulfonic acid, } \\
\text { ammonia }\end{array}$ & $\mathrm{mg} / \mathrm{L}$ & APHA (1999) \\
\hline & Fluoride $\left(\mathrm{F}^{-}\right)$ & $\begin{array}{l}\text { ISE (ion selective electrode; } \\
\text { Thermo Orion) }\end{array}$ & TISAB III and NaF & $\mathrm{mg} / \mathrm{L}$ & APHA (1999) \\
\hline \multirow[t]{4}{*}{ Irrigation water } & $\begin{array}{l}\text { Sodium absorption ratio } \\
\text { (SAR) }\end{array}$ & $\frac{\mathrm{Na}^{+}}{\sqrt{\left(\mathrm{Ca}^{2+}+\mathrm{Mg}^{2+}\right) / 2}}$ & - & $\mathrm{meq} / \mathrm{L}$ & Richards (1954) \\
\hline & $\begin{array}{l}\text { Residual sodium carbonate } \\
\text { (RSC) }\end{array}$ & $\begin{array}{c}\left(\mathrm{CO}_{3}^{-}+\mathrm{HCO}_{3}^{-}\right)- \\
\left(\mathrm{Ca}^{2+}+\mathrm{Mg}^{2+}\right)\end{array}$ & - & $\mathrm{meq} / \mathrm{L}$ & Eaton (1950) \\
\hline & Percent sodium $(\% \mathrm{Na})$ & $\frac{\mathrm{Na}^{+}+\mathrm{K}^{+}}{\left(\mathrm{Ca}^{2+}+\mathrm{Mg}^{2+}+\mathrm{Na}^{+}+\mathrm{K}^{+}\right)} \times 100$ & - & $\%$ & Wilcox (1955) \\
\hline & Magnesium hazard & $\mathrm{Mg}^{2+} \times 100 /\left(\mathrm{Ca}^{2+}+\mathrm{Mg}^{2+}\right)$ & - & $\mathrm{meq} / \mathrm{L}$ & Szabolcs and D \\
\hline
\end{tabular}


Dolomite and Magnesite of the groundwater samples are obtained using Visual MINTEQ (3.1) interactive.

\section{Results and discussion}

The $\mathrm{pH}$ of water is a very important indication of its quality and provides important piece of information regarding types of geochemical equilibrium (Hem 1985). The $\mathrm{pH}$ of the analyzed samples varies from 6.47 to 8.03 with a mean value of 7.09 in the study area, indicating alkaline nature (Tables 2, 3). pH values of all the collected samples are well within the safe limit as prescribed by
WHO (1990). Though pH has no direct effect on human health, all biochemical reactions are sensitive to variation of pH (Subba Rao and Krishna Rao 1991). The electric conductivity (EC) values for study area ranges from 235 to $2118 \mu \mathrm{S} / \mathrm{cm}$ at $25^{\circ} \mathrm{C}$ with an average value of $595.24 \mu \mathrm{S} /$ $\mathrm{cm}$ (Tables 2, 3). The higher EC may be attributed to high salinity and high mineral content at the sampling site (Vinod et al. 2009). It depends upon temperature, concentration and type of ions present in groundwater and also concentration of EC increases with the concentration of TDS. Total dissolved solids (TDS) in water comprise all inorganic salts including carbonate, bicarbonate, chloride, fluoride, sulfate, phosphate, nitrate, calcium,

Table 2 Analytical data for the groundwater samples from the study area (EC in $\mu \mathrm{S} / \mathrm{cm}$, remaining $\mathrm{mg} / \mathrm{L}$, except $\mathrm{pH}$ )

\begin{tabular}{|c|c|c|c|c|c|c|c|c|c|c|c|c|c|c|c|c|}
\hline Sample ID & Longitude & Latitude & $\mathrm{pH}$ & $\mathrm{EC}$ & TDS & $\mathrm{TH}$ & $\mathrm{CO}_{3}{ }^{2-}$ & $\mathrm{HCO}_{3}^{-}$ & $\mathrm{Cl}^{-}$ & $\mathrm{SO}_{4}{ }^{2-}$ & $\mathrm{NO}_{3}^{-}$ & $\mathrm{Ca}^{2+}$ & $\mathrm{Mg}^{2+}$ & $\mathrm{Na}^{+}$ & $\mathrm{K}^{+}$ & $\mathrm{F}^{-}$ \\
\hline BGW-1 & $77^{\circ} 58^{\prime} 11^{\prime \prime}$ & $18^{\circ} 51^{\prime} 17^{\prime \prime}$ & 6.61 & 392 & 251 & 160 & 0 & 85 & 128 & 42.5 & 22 & 42 & 13 & 76 & 4 & 0.37 \\
\hline BGW-2 & $77^{\circ} 58^{\prime} 53^{\prime \prime}$ & $18^{\circ} 51^{\prime} 42^{\prime \prime}$ & 6.61 & 863 & 552 & 325 & 0 & 152 & 340 & 75 & 60 & 104 & 16 & 122 & 25 & 0.57 \\
\hline BGW-3 & $77^{\circ} 59^{\prime} 42^{\prime \prime}$ & $18^{\circ} 51^{\prime} 31^{\prime \prime}$ & 7.02 & 314 & 201 & 150 & 0 & 110 & 64 & 25 & 17.5 & 38 & 13 & 47 & 3 & 0.74 \\
\hline BGW-4 & $77^{\circ} 56^{\prime} 49^{\prime \prime}$ & $18^{\circ} 51^{\prime} 32^{\prime \prime}$ & 6.57 & 235 & 150 & 115 & 0 & 85 & 50 & 5 & 4 & 30 & 9 & 15 & 8 & 0.46 \\
\hline BGW-5 & $77^{\circ} 55^{\prime} 46^{\prime \prime}$ & $18^{\circ} 51^{\prime} 29^{\prime \prime}$ & 7.24 & 549 & 351 & 40 & 21 & 140 & 96 & 75 & 38 & 10 & 4 & 154 & 2 & 2.2 \\
\hline BGW-6 & $77^{\circ} 55^{\prime} 21^{\prime \prime}$ & $18^{\circ} 52^{\prime} 32^{\prime \prime}$ & 7.61 & 863 & 552 & 80 & 18 & 350 & 113 & 150 & 40 & 20 & 7 & 250 & 3 & 2.22 \\
\hline BGW-7 & $77^{\circ} 55^{\prime} 21^{\prime \prime}$ & $18^{\circ} 53^{\prime} 33^{\prime \prime}$ & 7.52 & 2039 & 1305 & 650 & 12 & 134 & 638 & 375 & 24 & 105 & 10 & 420 & 4 & 0.91 \\
\hline BGW-8 & $77^{\circ} 54^{\prime} 59^{\prime \prime}$ & $18^{\circ} 54^{\prime} 13^{\prime \prime}$ & 6.47 & 2118 & 1355 & 850 & 0 & 98 & 1010 & 300 & 80 & 339 & 1 & 370 & 4 & 0.06 \\
\hline BGW-9 & $77^{\circ} 55^{\prime} 6^{\prime \prime}$ & $18^{\circ} 55^{\prime} 56^{\prime \prime}$ & 6.77 & 1177 & 753 & 500 & 33 & 128 & 110 & 250 & 38 & 125 & 22 & 120 & 5 & 0.48 \\
\hline BGW-10 & $77^{\circ} 55^{\prime} 9^{\prime \prime}$ & $18^{\circ} 57^{\prime} 6^{\prime \prime}$ & 7.62 & 392 & 251 & 35 & 12 & 135 & 53 & 120 & 42 & 10 & 2 & 161 & 4 & 2.56 \\
\hline BGW-11 & $77^{\circ} 54^{\prime} 55^{\prime \prime}$ & $18^{\circ} 58^{\prime} 27^{\prime \prime}$ & 8.03 & 471 & 301 & 85 & 15 & 128 & 50 & 80 & 40 & 8 & 16 & 121 & 4 & 2.48 \\
\hline BGW-12 & $77^{\circ} 56^{\prime} 12^{\prime \prime}$ & $18^{\circ} 58^{\prime} 16^{\prime \prime}$ & 7.3 & 392 & 251 & 115 & 18 & 125 & 89 & 50 & 35 & 38 & 5 & 118 & 4 & 1.19 \\
\hline BGW-13 & $77^{\circ} 55^{\prime} 36^{\prime \prime}$ & $18^{\circ} 59^{\prime} 26^{\prime \prime}$ & 6.9 & 471 & 301 & 160 & 15 & 98 & 124 & 50 & 15 & 36 & 17 & 102 & 1 & 1.12 \\
\hline BGW-14 & $77^{\circ} 56^{\prime} 6^{\prime \prime}$ & $18^{\circ} 59^{\prime} 1^{\prime \prime}$ & 7.53 & 314 & 201 & 110 & 15 & 120 & 43 & 7.5 & 32 & 26 & 11 & 63 & 2 & 1.13 \\
\hline BGW-15 & $77^{\circ} 56^{\prime} 30^{\prime \prime}$ & $18^{\circ} 59^{\prime} 32^{\prime \prime}$ & 7.62 & 314 & 201 & 150 & 12 & 110 & 74 & 12.5 & 13 & 40 & 12 & 49 & 2 & 0.96 \\
\hline BGW-16 & $77^{\circ} 57^{\prime} 3^{\prime \prime}$ & $18^{\circ} 58^{\prime} 48^{\prime \prime}$ & 6.78 & 549 & 351 & 250 & 18 & 49 & 266 & 17.5 & 60 & 66 & 21 & 95 & 2 & 0.94 \\
\hline BGW-17 & $77^{\circ} 58^{\prime} 14^{\prime \prime}$ & $18^{\circ} 59^{\prime} 35^{\prime \prime}$ & 6.97 & 314 & 201 & 85 & 15 & 61 & 89 & 7.5 & 4 & 32 & 1 & 46 & 2 & 0.54 \\
\hline BGW-18 & $77^{\circ} 59^{\prime} 17^{\prime \prime}$ & $18^{\circ} 58^{\prime} 51^{\prime \prime}$ & 7.27 & 314 & 201 & 35 & 15 & 110 & 64 & 2.5 & 130 & 10 & 2 & 119 & 2 & 4.33 \\
\hline BGW-19 & $77^{\circ} 58^{\prime} 20^{\prime \prime}$ & $18^{\circ} 58^{\prime} 41^{\prime \prime}$ & 6.52 & 549 & 351 & 270 & 15 & 61 & 227 & 25 & 0.8 & 66 & 25 & 82 & 3 & 0.43 \\
\hline BGW-20 & $77^{\circ} 57^{\prime} 37^{\prime \prime}$ & $18^{\circ} 58^{\prime} 5^{\prime \prime}$ & 7.42 & 471 & 301 & 75 & 18 & 125 & 96 & 27.5 & 42 & 18 & 7 & 129 & 3 & 1.46 \\
\hline BGW-21 & $77^{\circ} 58^{\prime} 19^{\prime \prime}$ & $18^{\circ} 57^{\prime} 45^{\prime \prime}$ & 7.07 & 314 & 201 & 95 & 18 & 79 & 42 & 5 & 56 & 24 & 8 & 66 & 3 & 1.43 \\
\hline BGW-22 & $77^{\circ} 58^{\prime} 41^{\prime \prime}$ & $18^{\circ} 57^{\prime} 5^{\prime \prime}$ & 7.28 & 471 & 301 & 150 & 21 & 103 & 120 & 37.5 & 35 & 20 & 24 & 110 & 3 & 2.44 \\
\hline BGW-23 & $77^{\circ} 58^{\prime} 80^{\prime \prime}$ & $18^{\circ} 56^{\prime} 85^{\prime \prime}$ & 6.57 & 627 & 401 & 235 & 9 & 67 & 287 & 20 & 56 & 68 & 16 & 120 & 7 & 0.27 \\
\hline BGW-24 & $77^{\circ} 56^{\prime} 48^{\prime \prime}$ & $18^{\circ} 56^{\prime} 49^{\prime \prime}$ & 7.16 & 863 & 552 & 210 & 24 & 116 & 467 & 50 & 60 & 36 & 29 & 312 & 4 & 2.03 \\
\hline BGW-25 & $77^{\circ} 57^{\prime} 44^{\prime \prime}$ & $18^{\circ} 57^{\prime} 9^{\prime \prime}$ & 7.21 & 471 & 301 & 90 & 30 & 120 & 89 & 51 & 48 & 28 & 4 & 139 & 4 & 1.25 \\
\hline BGW-26 & $77^{\circ} 58^{\prime} 27^{\prime \prime}$ & $18^{\circ} 56^{\prime} 8^{\prime \prime}$ & 7.18 & 314 & 201 & 125 & 15 & 85 & 85 & 15 & 2 & 38 & 7 & 61 & 4 & 0.76 \\
\hline BGW-27 & $77^{\circ} 58^{\prime} 1^{\prime \prime}$ & $18^{\circ} 54^{\prime} 57^{\prime \prime}$ & 6.89 & 392 & 251 & 185 & 12 & 134 & 74 & 10 & 27 & 38 & 21 & 43 & 4 & 0.86 \\
\hline BGW-28 & $77^{\circ} 59^{\prime} 22^{\prime \prime}$ & $18^{\circ} 54^{\prime} 2^{\prime \prime}$ & 6.91 & 706 & 452 & 160 & 15 & 165 & 227 & 32.5 & 35 & 42 & 13 & 169 & 5 & 0.78 \\
\hline BGW-29 & $77^{\circ} 58^{\prime} 35^{\prime \prime}$ & $18^{\circ} 53^{\prime} 10^{\prime \prime}$ & 7.15 & 627 & 401 & 210 & 30 & 183 & 252 & 25 & 32 & 85 & 6 & 120 & 39 & 0.26 \\
\hline BGW-30 & $77^{\circ} 57^{\prime} 20^{\prime \prime}$ & $18^{\circ} 53^{\prime} 28^{\prime \prime}$ & 6.84 & 392 & 251 & 170 & 18 & 104 & 156 & 37.5 & 8 & 50 & 10 & 92 & 4 & 0.75 \\
\hline BGW-31 & $77^{\circ} 56^{\prime} 34^{\prime \prime}$ & $18^{\circ} 53^{\prime} 10^{\prime \prime}$ & 6.71 & 549 & 251 & 315 & 24 & 122 & 308 & 17.5 & 60 & 102 & 14 & 94 & 16 & 0.71 \\
\hline BGW-32 & $77^{\circ} 56^{\prime} 45^{\prime \prime}$ & $18^{\circ} 52^{\prime} 14^{\prime \prime}$ & 7.73 & 235 & 150 & 95 & 30 & 73 & 89 & 27.5 & 25 & 22 & 10 & 89 & 5 & 0.54 \\
\hline BGW-33 & $77^{\circ} 57^{\prime} 19^{\prime \prime}$ & $18^{\circ} 52^{\prime} 24^{\prime \prime}$ & 6.68 & 627 & 401 & 310 & 0 & 98 & 234 & 50 & 18 & 104 & 12 & 107 & 5 & 0.11 \\
\hline BGW-34 & $77^{\circ} 58^{\prime} 19^{\prime \prime}$ & $18^{\circ} 52^{\prime} 26^{\prime \prime}$ & 7.44 & 549 & 351 & 120 & 18 & 250 & 110 & 50 & 42 & 18 & 18 & 191 & 4 & 1.02 \\
\hline
\end{tabular}

$B G W$ Basara groundwater 
Table 3 Concentrations of ions and their comparison with the WHO

\begin{tabular}{|c|c|c|c|c|c|c|}
\hline \multirow{2}{*}{$\begin{array}{l}\text { Chemical } \\
\text { parameters }\end{array}$} & \multirow[t]{2}{*}{ Expressed } & \multirow[t]{2}{*}{ Minimum } & \multirow[t]{2}{*}{ Maximum } & \multicolumn{2}{|l|}{ WHO (1990) } & \multirow{2}{*}{$\begin{array}{l}\text { Sample numbers exceeding } \\
\text { permissible limit }\end{array}$} \\
\hline & & & & Desirable limit & Permissible limit & \\
\hline $\mathrm{pH}$ & Units & 6.47 & 8.03 & $6.5-8.5$ & 9.2 & Nil \\
\hline $\mathrm{EC}$ & $\mu \mathrm{S} / \mathrm{cm}$ & 235 & 2118 & 750 & 1500 & 6,22 \\
\hline TDS & $\mathrm{mg} / \mathrm{L}$ & 150 & 1355 & 500 & 1500 & Nil \\
\hline $\mathrm{TH}$ & $\mathrm{mg} / \mathrm{L}$ & 35 & 850 & 100 & 500 & $7,8,9$ \\
\hline $\mathrm{HCO}_{3}{ }^{-}$ & $\mathrm{mg} / \mathrm{L}$ & 49 & 350 & - & - & - \\
\hline $\mathrm{CO}_{3}^{2-}$ & $\mathrm{mg} / \mathrm{L}$ & 0 & 33 & - & - & - \\
\hline $\mathrm{Cl}^{-}$ & $\mathrm{mg} / \mathrm{L}$ & 42 & 1010 & 250 & 600 & 7,8 \\
\hline $\mathrm{SO}_{4}^{2-}$ & $\mathrm{mg} / \mathrm{L}$ & 200 & 600 & 2.5 & 375 & Nil \\
\hline $\mathrm{NO}_{3}^{-}$ & $\mathrm{mg} / \mathrm{L}$ & 0.8 & 130 & - & 45 & $2,8,16,18,21,23,24,25,31$ \\
\hline $\mathrm{F}^{-}$ & $\mathrm{mg} / \mathrm{L}$ & 0.06 & 4.33 & 0.5 & 1.5 & $5,6,10,11,18,22,24$ \\
\hline $\mathrm{Na}^{+}$ & $\mathrm{mg} / \mathrm{L}$ & 15 & 420 & 50 & 200 & $6,7,8,24$ \\
\hline $\mathrm{K}^{+}$ & $\mathrm{mg} / \mathrm{L}$ & 1 & 39 & - & - & - \\
\hline $\mathrm{Ca}^{2+}$ & $\mathrm{mg} / \mathrm{L}$ & 8 & 339 & 75 & 200 & 8 \\
\hline $\mathrm{Mg}^{2+}$ & $\mathrm{mg} / \mathrm{L}$ & 1 & 29 & 30 & 150 & Nil \\
\hline
\end{tabular}

magnesium, sodium, and potassium (Sawyer 1994). Total dissolved solids of the groundwater, in the study area, vary from 150 to $1355 \mathrm{mg} / \mathrm{L}$ with an average of $377.82 \mathrm{mg} / \mathrm{L}$ (Tables 2, 3). The groundwater of the study area has been classified based on TDS values, according to the procedure suggested by US Geological Survey 2000. It is clear from Table 4 that $94.11 \%$ of groundwater samples fall into freshwater category, whereas $5.88 \%$ of groundwater

Table 4 Classification of groundwater based on irrigational water quality parameters

\begin{tabular}{|c|c|c|c|c|c|}
\hline Parameter & Classification & Range & $\begin{array}{l}\text { Number of } \\
\text { samples }\end{array}$ & $\%$ of samples & References \\
\hline \multirow[t]{4}{*}{ TDS } & Fresh water & $<1000$ & 32 & 94.11 & \multirow[t]{4}{*}{ US Geological Survey (2000) } \\
\hline & Slightly saline & $1000-3000$ & 2 & 5.88 & \\
\hline & Moderately saline & $3000-10,000$ & Nil & Nil & \\
\hline & High saline & $10,000-35,000$ & Nil & Nil & \\
\hline \multirow[t]{4}{*}{$\mathrm{TH}$} & Safe & $<75$ & 3 & 8.82 & \multirow[t]{4}{*}{ Sawyer et al. (2003) } \\
\hline & Moderate-hard & $75-150$ & 12 & 35.29 & \\
\hline & Hard & $150-300$ & 13 & 38.23 & \\
\hline & Very hard & $>300$ & 6 & 17.64 & \\
\hline \multirow[t]{4}{*}{ Salinity hazard } & Excellent $(\mathrm{C} 1)$ & Up to 250 & 2 & 5.88 & \multirow[t]{4}{*}{ Richards (1954), Todd (1980) } \\
\hline & Good (C2) & $250-750$ & 27 & 79.41 & \\
\hline & Fail/medium (C3) & $750-2250$ & 5 & 14.7 & \\
\hline & Poor/bad (C4) & $>2250$ & Nil & Nil & \\
\hline \multirow[t]{4}{*}{ Alkali hazard } & Excellent (S1) & Up to 10 & 31 & 91.17 & \multirow[t]{4}{*}{ Richards (1954), Todd (1980) } \\
\hline & Good (S2) & $10-18$ & 3 & 8.82 & \\
\hline & Fail/medium (S3) & $18-26$ & Nil & Nil & \\
\hline & Poor/bad (S4 \& S5) & $>26$ & Nil & Nil & \\
\hline \multirow[t]{2}{*}{ Percent sodium (\%Na) } & Safe & $<60$ & 20 & 59 & \multirow[t]{2}{*}{ Eaton (1950) } \\
\hline & Unsafe & $>60$ & 14 & 41 & \\
\hline \multirow[t]{3}{*}{$\mathrm{RSC}$} & Good & $<1.25$ & 31 & 91 & \multirow[t]{3}{*}{ Richards (1954) } \\
\hline & Doubtful & $1.25-2.50$ & 9 & 9 & \\
\hline & Unsuitable & $>2.50$ & Nil & Nil & \\
\hline \multirow[t]{2}{*}{ Magnesium hazard } & Suitable & $<50$ & 30 & 88 & \multirow[t]{2}{*}{ Szabolcs and Darab (1964) } \\
\hline & Unsuitable & $>50$ & 4 & 12 & \\
\hline
\end{tabular}


samples fall into slightly saline category (Table 4). The acceptable limit of total hardness $(\mathrm{TH})\left(\right.$ as $\mathrm{CaCO}_{3}$ ) is $300 \mathrm{mg} / \mathrm{L}$, which can be extended up to $600 \mathrm{mg} / \mathrm{L}$ in case of non-availability of any alternate water source (WHO 1990). The total hardness as $\mathrm{CaCO}_{3}$ equivalents in the study area ranges from 35 to $850 \mathrm{mg} / \mathrm{L}$ with mean value of $197.35 \mathrm{mg} / \mathrm{L}$ (Tables 2, 3). Sawyer et al. (2003) classified groundwater is given in Table 4, according to which $35.29 \%$ of samples belongs to moderate-hard type, and 38.23 and $17.64 \%$ of water belong to hard and very hard type, respectively.

\section{Carbonate $\left(\mathrm{CO}_{3}{ }^{2-}\right)$ and bicarbonate $\left(\mathrm{HCO}_{3}{ }^{-}\right)$}

Carbonate $\left(\mathrm{CO}_{3}{ }^{2-}\right)$ and bicarbonate $\left(\mathrm{HCO}_{3}{ }^{-}\right)$in the groundwater is varying from 0 to $33 \mathrm{mg} / \mathrm{L}$ and 43 to $183 \mathrm{mg} / \mathrm{L}$ with an average value of 15.17 and $104.44 \mathrm{mg} / \mathrm{L}$, respectively (Tables 2, 3). The content of $\mathrm{HCO}_{3}{ }^{-}$has no known adverse health effects and all groundwater samples lie within the desirable limit of $300 \mathrm{mg} / \mathrm{L}$ (WHO 1990; Table 3).

\section{Chloride $\left(\mathrm{Cl}^{-}\right)$and sulfate $\left(\mathrm{SO}_{4}{ }^{2-}\right)$}

The chloride concentration in the groundwater samples vary from 42 to $1010 \mathrm{mg} / \mathrm{L}$ with an average value of $182.06 \mathrm{mg} / \mathrm{L}$ (Tables 2,3). The desirable limit of chloride in potable water is $250 \mathrm{mg} / \mathrm{L}$ and the permissible limit is $1000 \mathrm{mg} / \mathrm{L}$ (WHO 1990), while $23.52 \%$ of the groundwater samples exceed the desirable limit, only one sample in the study area exceed the permissible limit. Excess of $\mathrm{Cl}^{-}$in the water is usually taken as an index of pollution and considered as tracer for groundwater contamination (Loizidou and Kapetanios 1993). Shand (1952) indicated that residual water contained in pores of granites or within the crystals of rocks may contain chloride. Chloride is higher $(1010 \mathrm{mg} / \mathrm{L}$ in Bederelli village) due to leaching of upper soil layers by industrial and domestic activities and dry climates; furthermore, higher concentration of $\mathrm{Cl}^{-}$in drinking water causes a salty taste and has a laxative effect in people not accustomed to it (Bhardwaj and Singh 2011). The sulfate concentration of the groundwater samples of the study area ranges from 2.5 to $375 \mathrm{mg} / \mathrm{L}$ with an average value of $56.985 \mathrm{mg} / \mathrm{L}$, which is below the permissible limit of $400 \mathrm{mg} / \mathrm{L}$ (WHO 1990).

\section{Nitrate $\left(\mathrm{NO}_{3}{ }^{-}\right)$and fluoride $\left(\mathrm{F}^{-}\right)$}

Nitrate contamination in groundwater is one of the major issues in water quality studies (Schilling and Wolter 2007; Narsimha and Sudarshan 2017a). Nitrate concentration in the groundwater of the study area varies from 0.4 to $80 \mathrm{mg} / \mathrm{L}$ with mean $22.068 \mathrm{mg} / \mathrm{L}$ (Tables 2, 3). The highest nitrate level is recorded at Bederelli village $(80 \mathrm{mg} / \mathrm{L})$, Aljapur, Vitholi thanda and near Basara $(60 \mathrm{mg} / \mathrm{L}), 20.58 \%$ of the groundwater contains excess nitrate (above $45 \mathrm{mg} / \mathrm{L}$ ) in the study area, which is not suitable for drinking purpose. Presence of high concentration of nitrate in drinking water not only causes methemoglobinemia in infants, but has also been reported to cause cancer (Dissanayake et al. 1987). The fluoride content in the groundwater shows a range of $0.06-4.33 \mathrm{mg} / \mathrm{L}$ and the average value is $1.13 \mathrm{mg} / \mathrm{L}$ with highest fluoride level recorded at Karegaon village $(4.33 \mathrm{mg} / \mathrm{L})$, lowest at Bederelli village $(0.06 \mathrm{mg} / \mathrm{L})$ and $>2$ to $<3 \mathrm{mg} / \mathrm{L}$ in Basara RS, Mudhole, Gannora and Bamanagon villages. Nearly $41 \%$ of groundwater of the study area has more than $1.00 \mathrm{mg} / \mathrm{L}$ of fluoride which is the desirable limit and $20 \%$ of the groundwater has more than $1.5 \mathrm{mg} / \mathrm{L}$ of fluoride which is the permissible limit for drinking purposes. The present study region is occupied by Granitic rocks and these are well known to contain a relatively larger proportion of high-fluorine minerals (Edmunds and Smedley 2005; Adimalla and Venkatayogi 2017; Narsimha and Sudarshan 2013). Fluorite, the main mineral that controls the geochemistry of fluoride in most environments, is found in significant amount in granite, granite gneisses, and pegmatite (Narsimha and Sudarshan 2017a, b; Adimalla and Venkatayogi 2017; Chae et al. 2007; Deshmukh et al. 1995).

\section{Sodium $\left(\mathrm{Na}^{+}\right)$and potassium $\left(\mathrm{K}^{+}\right)$}

Sodium is one of the most important constituents of groundwater because its higher concentration, more than $200 \mathrm{mg} / \mathrm{L}$, makes the water unsuitable for domestic use and causes severe health problems like hypertension, congenial diseases, kidney disorders and nervous disorders in human body (Vinod et al. 2009; Narsimha and Sudarshan 2017a). Sodium concentration in groundwater ranges from 15 to $810 \mathrm{mg} / \mathrm{L}$ with an average of $146 \mathrm{mg} / \mathrm{L}$ (Tables 2, 3). According to WHO (1990) guidelines, the maximum admissible limit is $200 \mathrm{mg} / \mathrm{L}$ and $15 \%$ of the samples are above this limit. The concentration of potassium in natural water is generally less than $10 \mathrm{mg} / \mathrm{L}$ (WHO 1990). The potassium concentration in groundwater in the study area varies from 1 to $39 \mathrm{mg} / \mathrm{L}$ with an average value of $5.71 \mathrm{mg} / \mathrm{L}$. The permissible limit of $\mathrm{K}^{+}$for drinking water is specified as $12 \mathrm{mg} / \mathrm{L}$ as per WHO (1990) and $8.82 \%$ of the samples are above this limit.

\section{Calcium $\left(\mathrm{Ca}^{2+}\right)$ and magnesium $\left(\mathrm{Mg}^{2+}\right)$}

Calcium in the groundwater of the study area is varying from 8 to $339 \mathrm{mg} / \mathrm{L}$ with an average value of $59 \mathrm{mg} / \mathrm{L}$ (Tables 2 , $3)$. The presence of large amount of carbon dioxide may increase the solubility of calcium up to $200-300 \mathrm{mg} / \mathrm{L}$ in the presence of bicarbonate (Hem 1985; Karanth 1989). The maximum admissible limit for calcium is $200 \mathrm{mg} / \mathrm{L}$ (WHO 1990). Only $6 \%$ of groundwater of the study area has $\mathrm{Ca}^{2+}$ 
concentration above the permissible limit suggested by WHO (1990) (Table 3). Magnesium in the groundwater of the study area is varying from 1 to $29 \mathrm{mg} / \mathrm{L}$ and the average value is $11.94 \mathrm{mg} / \mathrm{L}$ (Tables 2,3 ). The required permissible limit of magnesium in groundwater for drinking purpose is $30 \mathrm{mg} / \mathrm{L}$ (WHO 1990) and the concentrations are found to be within the permissible limits (Tables 2, 3).

\section{Geochemical diagrams/classification of groundwater}

Hydrochemical diagrams are aimed at facilitating interpretation of evolutionary trends, particularly in groundwater systems, when they are interpreted in conjunction with distribution maps and hydrochemical sections. For these purposes, Chadha (1999), Gibbs (1970), Soltan (1999) and hydrogeochemical saturation index states have been emphasized to better understand the groundwater system.

\section{Chadha diagram}

The term "hydrochemical facies" is used to describe occurrence modes of groundwater in an aquifer that differs in their chemical composition. Classification of geochemical facies and interpretation of chemical data of groundwater can be classified on the basis of dominant ions using the Chadha rectangular diagram (Chadha 1999). In the proposed diagram (Fig. 2), the differences in milliequivalent percentage between alkaline earths $\left(\mathrm{Ca}^{2+}+\mathrm{Mg}^{2+}\right)$ and alkali metals $\left(\mathrm{Na}^{+}+\mathrm{K}^{+}\right)$, expressed as percentage reacting values, are plotted on the $x$-axis, and the differences in milliequivalent percentage between weak acidic anions $\left(\mathrm{CO}_{3}{ }^{2-}+\mathrm{HCO}_{3}{ }^{-}\right)$ and strong acidic anions $\left(\mathrm{Cl}^{-}+\mathrm{SO}_{4}{ }^{2-}\right)$ are plotted on the $y$-axis. Results of chemical analyses were plotted on the proposed diagram to test its applicability for geochemical classification of groundwater and to understand the hydrochemical processes shown in Fig. 2. The majority of groundwater samples $(50 \%$, Fig. 2$)$ in the study area fall under the subfield of $\mathrm{Na}^{+}-\mathrm{Cl}^{-}$water type with salinity problems both in irrigation and domestic uses. The $29 \%$ of the groundwater samples fall under the subfield of alkaline earths exceeding alkali metals and strong acidic anions exceeding weak acidic anions $\left(\mathrm{Ca}^{2+}-\mathrm{Mg}^{2+}-\mathrm{Cl}^{-}\right.$type $)$, such waters have permanent hardness. The remaining $18 \%$ of the water samples concentrate in the category of $\mathrm{Na}^{+}-\mathrm{HCO}_{3}{ }^{-}$type (Fig. 2); such waters release residual sodium carbonate while irrigating and cause foaming problems when used for domestic purposes. Only $3 \%$ of groundwater samples fell in alkaline earths and weak acidic anions that exceed both alkali metals and strong acidic anions $\left(\mathrm{Ca}^{2+}-\mathrm{Mg}^{2+}-\mathrm{HCO}_{3}{ }^{-}\right.$type $)$such waters may have temporary hardness.

\section{Gibbs diagram}

Gibbs diagrams for cations $\left(\mathrm{Na}^{+}+\mathrm{K}^{+}\right) /\left(\mathrm{Na}^{+}+\mathrm{K}^{+}+\mathrm{Ca}^{2+}\right)$ and anions $\left(\mathrm{Cl}^{-}\right) /\left(\mathrm{Cl}^{-}+\mathrm{HCO}_{3}^{-}\right)$of the groundwater samples
Fig. 2 Geochemical classification and hydrochemical parameters of groundwater (after Chadha 1999). 1. Alkaline earths exceed alkali metals; 2 . alkali metals exceed alkaline earths; 3 . weak acidic anions exceed strong acidic anions; 4. strong acidic anions exceed weak acidic anions; 5 . $\mathrm{Ca}^{2+}$ $\mathrm{Mg}^{2+}-\mathrm{HCO}_{3}{ }^{-}$water type with temporary hardness; 6 . $\mathrm{Ca}^{2+}-$ $\mathrm{Mg}^{2+}-\mathrm{Cl}^{-}$water type with permanent hardness; 7 . $\mathrm{Na}^{+}$ $\mathrm{Cl}^{-}$water type with salinity problems both in irrigation and domestic uses; $8 . \mathrm{Na}^{+}-\mathrm{HCO}_{3}{ }^{-}$ water type causes foaming problems in domestic use

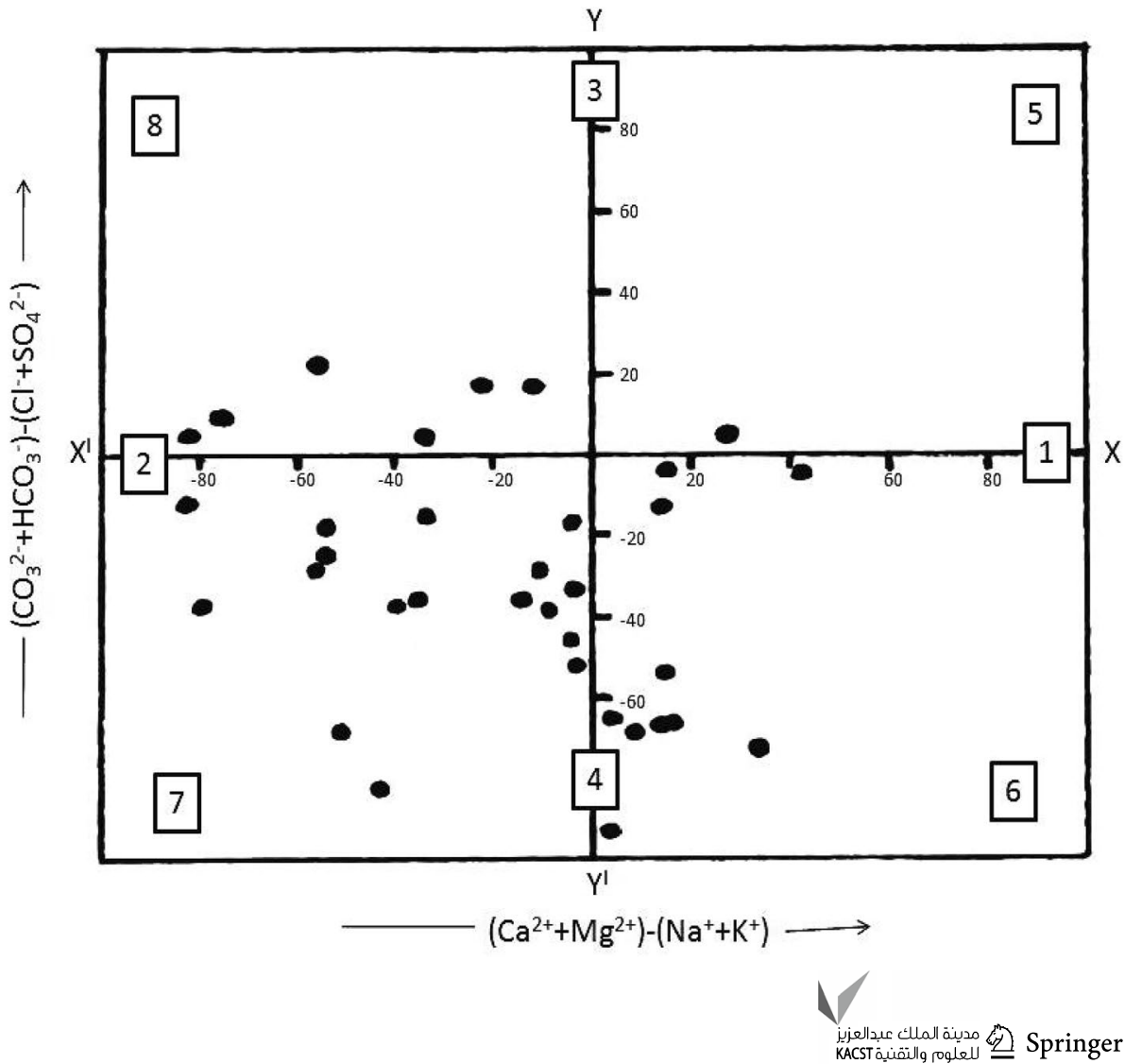


Fig. 3 Mechanism controlling groundwater chemistry of the Basara region (Gibbs 1970). a TDS vs $\left(\mathrm{Na}^{+}+\mathrm{K}^{+}\right):\left(\mathrm{Na}^{+}+\mathrm{K}^{+}+\mathrm{Ca}^{2+}\right)$ and b TDS vs $\left(\mathrm{Cl}^{-}: \mathrm{Cl}^{-}+\mathrm{HCO}_{3}^{-}\right)$were showing rock, evaporation and precipitation dominance

were plotted separately against TDS (Gibbs 1970; Ramesam and Barua 1973; Adimalla and Venkatayogi 2017; Viswanathaiah et al. 1978; Narsimha and Sudarshan 2017a, b) to assess the rock dominance, evaporation dominance and precipitation dominance in groundwater chemistry (Fig. 3). The present study reveals that the groundwater chemistry majorly influenced by the rock dominance, which indicates that the foremost mechanism of weathering of rocks forming minerals due to the entire province of occupied by granitic gneisses. Eventually, few groundwater locations were inclined towards evaporation which indicates influence of anthropogenic activity is prevalent, leading to increase in concentration of sodium, chloride and also TDS (Adimalla and Venkatayogi 2017; Narsimha and Sudarshan 2017b).

\section{Soltan classification}

Soltan (1999) has clearly classified groundwater into two types, which are base-exchange indices $(r 1)$ and meteoric genesis indices $(r 2)$ as shown below.

$$
r 1=\left(\mathrm{Na}^{+}-\mathrm{Cl}^{-}\right) / \mathrm{SO}_{4}{ }^{2-}
$$

$r 2=\left[\left(\mathrm{K}^{+}+\mathrm{Na}^{+}\right)-\mathrm{Cl}^{-}\right] / \mathrm{SO}_{4}{ }^{2-}$, where $\mathrm{Na}^{+}, \mathrm{K}^{+}, \mathrm{Cl}^{-}$and $\mathrm{SO}_{4}{ }^{2-}$ concentrations are expressed in meq/L. If $r 1<1$ and $r 2<1$, the groundwater sources are of $\mathrm{Na}^{+}-\mathrm{SO}_{4}{ }^{2-}$ and deep meteoric type, respectively, while $r 1>1$ and $r 2>1$ indicates the sources are of $\mathrm{Na}^{+}-\mathrm{HCO}_{3}{ }^{-}$and shallow meteoric type, respectively, and also presented in Table 5. Based on Soltan classification 59\% of groundwater belongs to $\mathrm{Na}^{+}-\mathrm{SO}_{4}{ }^{2-}$, rest of the samples is of $\mathrm{Na}^{+}-\mathrm{HCO}_{3}{ }^{-}$, while $56 \%$ of groundwater belongs to deep meteoric and $44 \%$ of are of shallow meteoric type.

\section{Hydrogeochemical saturation index states}

The saturation state of minerals in the groundwater can be expressed by the saturation index (SI). The saturation index (SI) is vital to envisage the subsurface mineralogy from groundwater data without collecting the samples of the solid phase and analyzing the mineralogy (Deutsch 1997). Moreover, Frenkel (1984) has concluded that arid and semi-arid regions of surface and subsurface water was nearly saturated with respect to $\mathrm{CaCO}_{3}$, and also contains high concentrations of sulfate and calcium which could be precipitated in the soil. Visual MINTEQ (3.1) has widely been used to estimate the saturation index (SI) of the groundwater with respect to mineral phases (Gustafsson 2012; Nagaraju et al. 2014; Appelo and Postma 1996). The solubility products of several minerals which a
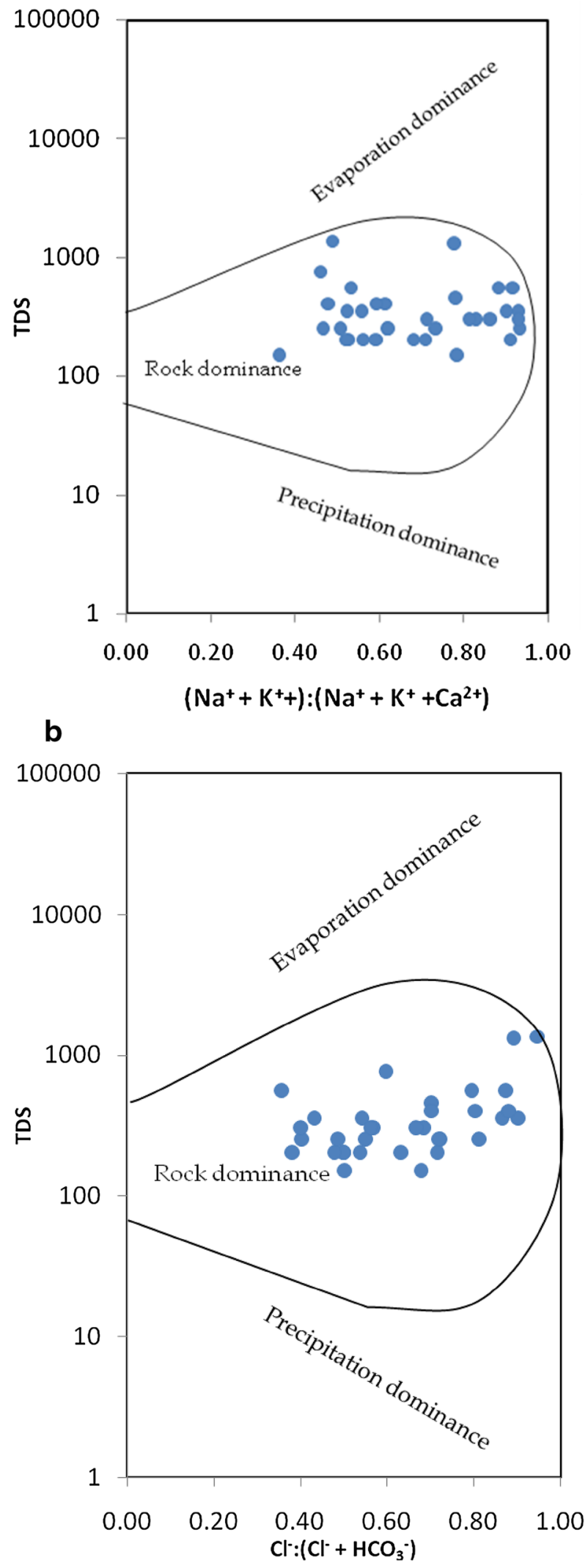
Table 5 Groundwater classification according to base-exchange $(r 1)$ and meteoric genesis index $(r 2)$ criteria

\begin{tabular}{|c|c|c|c|c|}
\hline Sample no. & $\underline{r} 1$ & Water type & $r 2$ & Water type \\
\hline BGW-1 & -0.34 & $\mathrm{Na}^{+}-\mathrm{SO}_{4}{ }^{2-}$ & -0.23 & Deep meteoric \\
\hline BGW-2 & -2.74 & $\mathrm{Na}^{+}-\mathrm{SO}_{4}{ }^{2-}$ & -2.33 & Deep meteoric \\
\hline BGW-3 & 0.46 & $\mathrm{Na}^{+}-\mathrm{SO}_{4}{ }^{2-}$ & 0.61 & Deep meteoric \\
\hline BGW-4 & -7.28 & $\mathrm{Na}^{+}-\mathrm{SO}_{4}{ }^{2-}$ & -5.32 & Deep meteoric \\
\hline BGW-5 & 2.56 & $\mathrm{Na}^{+}-\mathrm{HCO}_{3}^{-}$ & 2.59 & Shallow meteoric \\
\hline BGW-6 & 2.46 & $\mathrm{Na}^{+}-\mathrm{HCO}_{3}{ }^{-}$ & 2.49 & Shallow meteoric \\
\hline BGW-7 & 0.03 & $\mathrm{Na}^{+}-\mathrm{SO}_{4}{ }^{2-}$ & 0.05 & Deep meteoric \\
\hline BGW-8 & -1.98 & $\mathrm{Na}^{+}-\mathrm{SO}_{4}{ }^{2-}$ & -1.97 & Deep meteoric \\
\hline BGW-9 & 0.41 & $\mathrm{Na}^{+}-\mathrm{SO}_{4}{ }^{2-}$ & 0.43 & Deep meteoric \\
\hline BGW-10 & 2.20 & $\mathrm{Na}^{+}-\mathrm{HCO}_{3}{ }^{-}$ & 2.25 & Shallow meteori \\
\hline BGW-11 & 2.31 & $\mathrm{Na}^{+}-\mathrm{HCO}_{3}{ }^{-}$ & 2.37 & Shallow meteori \\
\hline BGW-12 & 2.52 & $\mathrm{Na}^{+}-\mathrm{HCO}_{3}^{-}$ & 2.62 & Shallow meteori \\
\hline BGW-13 & 0.90 & $\mathrm{Na}^{+}-\mathrm{SO}_{4}{ }^{2-}$ & 0.93 & Deep meteoric \\
\hline BGW-14 & 9.78 & $\mathrm{Na}^{+}-\mathrm{HCO}_{3}^{-}$ & 10.11 & Shallow meteoric \\
\hline BGW-15 & 0.17 & $\mathrm{Na}^{+}-\mathrm{SO}_{4}{ }^{2-}$ & 0.37 & Deep meteoric \\
\hline BGW-16 & -9.25 & $\mathrm{Na}^{+}-\mathrm{SO}_{4}{ }^{2-}$ & -9.11 & Deep meteoric \\
\hline BGW-17 & -3.26 & $\mathrm{Na}^{+}-\mathrm{SO}_{4}{ }^{2-}$ & -2.94 & Deep meteoric \\
\hline BGW-18 & 64.77 & $\mathrm{Na}^{+}-\mathrm{HCO}_{3}^{-}$ & 65.75 & Shallow meteori \\
\hline BGW-19 & -5.45 & $\mathrm{Na}^{+}-\mathrm{SO}_{4}{ }^{2-}$ & -5.30 & Deep meteoric \\
\hline BGW-20 & 5.07 & $\mathrm{Na}^{+}-\mathrm{HCO}_{3}{ }^{-}$ & 5.20 & Shallow meteoric \\
\hline BGW-21 & 16.20 & $\mathrm{Na}^{+}-\mathrm{HCO}_{3}{ }^{-}$ & 16.93 & Shallow meteori \\
\hline BGW-22 & 1.79 & $\mathrm{Na}^{+}-\mathrm{HCO}_{3}^{-}$ & 1.89 & Shallow meteoric \\
\hline BGW-23 & -6.91 & $\mathrm{Na}^{+}-\mathrm{SO}_{4}{ }^{2-}$ & -6.48 & Deep meteoric \\
\hline BGW-24 & 0.38 & $\mathrm{Na}^{+}-\mathrm{SO}_{4}{ }^{2-}$ & 0.48 & Deep meteoric \\
\hline BGW-25 & 3.33 & $\mathrm{Na}^{+}-\mathrm{HCO}_{3}^{-}$ & 3.43 & Shallow meteoric \\
\hline BGW-26 & 0.82 & $\mathrm{Na}^{+}-\mathrm{SO}_{4}{ }^{2-}$ & 1.15 & Shallow meteori \\
\hline BGW-27 & -1.04 & $\mathrm{Na}^{+}-\mathrm{SO}_{4}{ }^{2-}$ & -0.55 & Deep meteoric \\
\hline BGW-28 & 1.40 & $\mathrm{Na}^{+}-\mathrm{HCO}_{3}^{-}$ & 1.59 & Shallow meteoric \\
\hline BGW-29 & -3.63 & $\mathrm{Na}^{+}-\mathrm{SO}_{4}{ }^{2-}$ & -1.71 & Deep meteoric \\
\hline BGW-30 & -0.51 & $\mathrm{Na}^{+}-\mathrm{SO}_{4}{ }^{2-}$ & -0.38 & Deep meteoric \\
\hline BGW-31 & -12.62 & $\mathrm{Na}^{+}-\mathrm{SO}_{4}{ }^{2-}$ & -11.50 & Deep meteoric \\
\hline BGW-32 & 2.38 & $\mathrm{Na}^{+}-\mathrm{HCO}_{3}{ }^{-}$ & 2.60 & Shallow meteoric \\
\hline BGW-33 & -1.87 & $\mathrm{Na}^{+}-\mathrm{SO}_{4}^{2-}$ & -1.75 & Deep meteoric \\
\hline BGW-34 & 5.00 & $\mathrm{Na}^{+}-\mathrm{HCO}_{3}{ }^{-}$ & 5.10 & Shallow meteoric \\
\hline
\end{tabular}

might be expected to precipitate from irrigation waters are provided in supplementary material Table 1 . If $\mathrm{SI}=0$, there is equilibrium between the mineral and the solution; SI $<0$ reflects under saturation (dissolution) with respect to that particular mineral, and SI $>0$ oversaturation. The calculated values of SI for Anhydrite, Aragonite, Artinite, Brucite, Calcite, Fluorite, Gypsum, Dolomite and Magnesite of the groundwater samples ranged from -4.13 to $-1.08,-3.13$ to $-1.19,-12.34$ to $-8.84,-7.87$ to $-6.29,-2.99$ to $-1.05,-2.92$ to $-0.61,-3.88$ to
Table 6 Saturation indexes of minerals minimum and maximum for groundwater in the semi-arid region of Basara, Telangana State, South India

\begin{tabular}{lrr}
\hline Minerals name & Minimum & Maximum \\
\hline Anhydrite & -4.13 & -1.08 \\
Aragonite & -3.13 & -1.19 \\
Artinite & -12.34 & -8.84 \\
Brucite & -7.87 & -6.29 \\
Calcite & -2.99 & -1.05 \\
Dolomite & -6.15 & -2.49 \\
Epsomite & -6.85 & -4.11 \\
Fluorite & -2.92 & -0.61 \\
Gypsum & -3.88 & -0.83 \\
Halite & -7.65 & -5.06 \\
Huntite & -16.83 & -9.72 \\
Hydromagnesite & -29.88 & -20.65 \\
Lime & -22.59 & -21.16 \\
Magnesite & -4.51 & -2.59 \\
Mirabilite & -9.77 & -5.29 \\
Natron & -13.34 & -9.42 \\
Nesquehonite & -7.30 & -5.38 \\
Periclase & -12.35 & -10.77 \\
Portlandite & -12.60 & -11.16 \\
Thenardite & -11.21 & -6.72 \\
Thermonatrite & -15.29 & -11.37 \\
Vaterite & -3.56 & -1.61 \\
\hline & &
\end{tabular}

$-0.83,-6.15$ to -2.49 and -4.51 to -2.59 , respectively (Table 6), which clearly shows all SI values were less than zero, indicating under-saturation (Fig. 4).

\section{Chemical characterization of hydrogeochemical data}

Chemical characterization of groundwater schemes developed are mainly based on the concentrations of various predominant cations and anions or on the interrelationship of ions and also a number of techniques and methods have been developed to interpret the chemical data. In this study, the groundwater quality with respect to irrigation/agricultural is assessed by the following methods:

1. Sodium adsorption ratio (SAR).

2. Electrical conductivity and percent sodium $(\% \mathrm{Na})$.

3. Residual sodium carbonate (RSC).

4. Magnesium hazard.

\section{Sodium adsorption ratio (SAR)}

Excess sodium in water produces the undesirable effects of changing soil properties and reducing soil permeability. 
Fig. 4 Saturation indices of groundwater samples with respect to Anhydrite, Brucite, Aragonite, Calcite, Dolomite, Gypsum and Fluorite

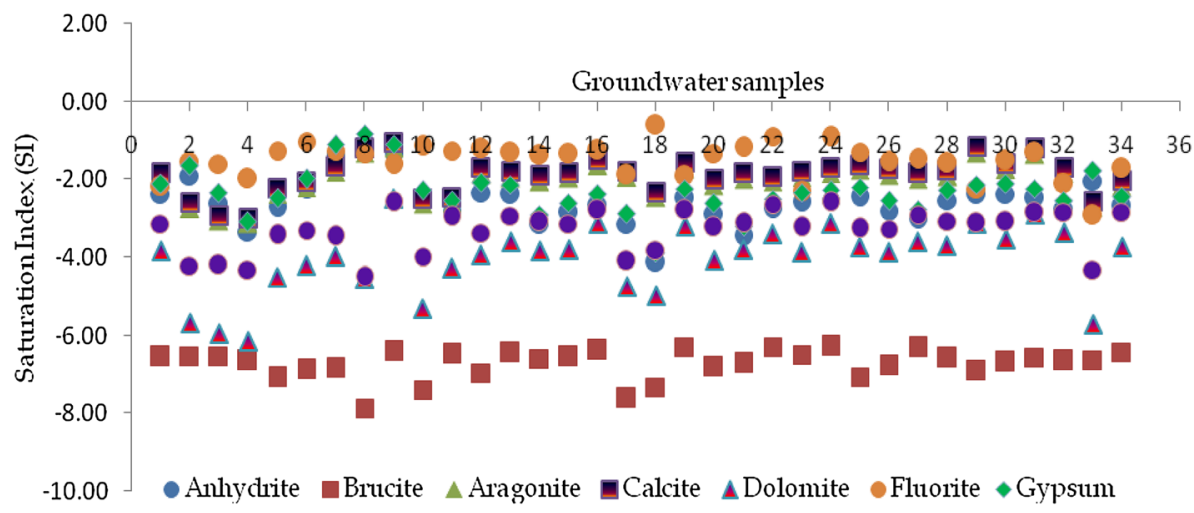

Hence, for considering the suitability for irrigation the assessment of sodium concentration is essential. The sodium or alkali hazard in the use of water for irrigation is determined by the absolute and relative concentration of cations. The relative activity of sodium ion in the exchange reaction with soil is expressed in terms of sodium adsorption ratio (SAR). The SAR, which indicates the effect of relative cation concentration on $\mathrm{Na}^{+}$accumulation in the soil, is used for evaluating the sodicity of irrigation water. The sodicity hazard of water is generally described by the SAR:
Fig. 5 Classification of irrigation water quality, with respect to salinity hazard and sodium hazard (after US Salinity Laboratory 1954)

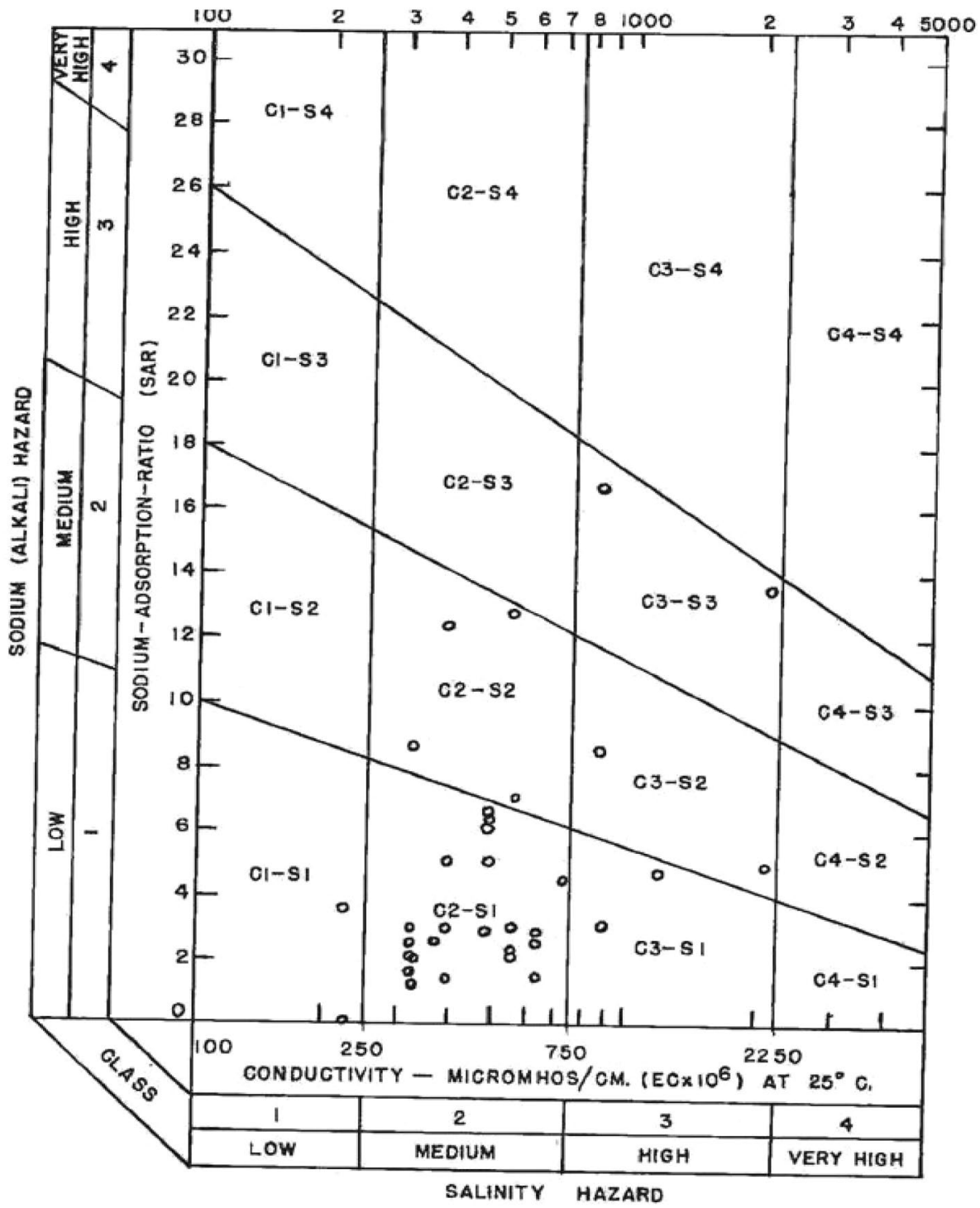


$\mathrm{SAR}=\frac{\mathrm{Na}}{\sqrt{(\mathrm{Ca}+\mathrm{Mg}) / 2}}$

The plot of the analytical data on the US Salinity Laboratory (1954) in which the EC is taken as salinity hazard and SAR as an alkalinity hazard (Fig. 5) shows that $64.70 \%$ (Table 4) fall into the category of $\mathrm{C} 2 \mathrm{~S} 1$, indicating medium salinity and low alkalinity water which can be used for irrigating most of the soil and crops with little danger of exchangeable sodium. $12 \%$ of samples which falls into $\mathrm{C} 2 \mathrm{~S} 2$ class indicate medium salinity medium sodium hazard. $5.88 \%$ of samples which falls into C1S1 class indicate low salinity and low alkalinity water. It can be used for irrigation for most soil and crops with less negative impact (Richards 1954). $5.88 \%$ of the water samples falls into C $3 S 1$ class, which shows a high salinity hazard and low alkalinity hazard. However, $5.88 \%$ of sample falls into C3S2 type (high salinity and medium sodium hazards). These types of water may be used on coarse-textured or organic soils with good permeability (Karanth 1989). 5.88\% of samples fall into C3S3 class (Fig. 5; high salinity and high sodium hazards).

\section{Electrical conductivity and percent sodium}

EC and Na concentrations are important in classifying irrigation water. The EC values vary from 235 to $2118 \mu \mathrm{S} / \mathrm{cm}$ (Tables 1, 2). High salt content (high EC) in irrigation water leads to formation of saline soil. Salinity, on the irrigated lands is the major cause of loss of production, and it has adverse environmental impacts on irrigation. Saline conditions severely limit the choice of crops and adversely affect crop germination and yields. It is important that all evaluations regarding irrigation water quality are linked to the evaluation of the soils to be irrigated. Sodium concentration is important in classifying irrigation water because sodium reacts with soil to reduce its permeability. In all natural waters, percent sodium is a parameter to evaluate its suitability for agricultural purposes (Wilcox 1955); sodium combining with carbonate forms alkaline soils, while sodium combining with chloride forms saline soils. Either type of sodium-enriched soil will support little or no plant growth (Todd 1980). The sodium percentage $(\% \mathrm{Na})$ in the study area ranges from 27.90 to 91.46 . A high sodium percentage causes deflocculation and impairment of the tithe and the permeability of soils (Karanth 1989).

$\% \mathrm{Na}=\frac{\mathrm{Na}^{+}+\mathrm{K}^{+}}{\left(\mathrm{Ca}^{2+}+\mathrm{Mg}^{2+}+\mathrm{Na}^{+}+\mathrm{K}^{+}\right)} \times 100$.

The chemical quality of groundwater samples was studied by plotting analytical data (Wilcox 1955) relating EC and sodium percent (Fig. 6) that show that out of the 34 groundwater samples, $59 \%$ of the samples belong to excellent to good category followed by $6 \%$ of the samples belonging to good to permissible category, $26 \%$ belonging to permissible to doubtful, and $9 \%$ of the samples belonging to doubtful to unsuitable category for irrigation uses (Table 4). The agricultural yields are generally low in lands irrigated with waters belonging to doubtful to unsuitable category. This is probably due to the presence of excess sodium salts, which cause osmotic effects on soil-plant system.

\section{Residual sodium carbonate (RSC)}

Residual sodium carbonate (RSC) also influences the suitability of groundwater for irrigation uses. Residual sodium carbonate can be estimated by subtracting the quality of alkaline earths $\left(\mathrm{Ca}^{2+}+\mathrm{Mg}^{2+}\right)$ from the carbonate $\left(\mathrm{CO}_{3}{ }^{2-}+\mathrm{HCO}_{3}^{-}\right)$. When the sum of carbonates is in excess of calcium and magnesium, there may be a possibility of complete precipitation of calcium and magnesium (Ragunath 1987). As a result, the relative proportion of sodium in the water is increased in the form of sodium carbonate, and this excess, denoted by RSC, is calculated as follows (Eaton 1950; Ragunath 1987):

$\mathrm{RSC}=\left(\mathrm{CO}_{3}{ }^{2-}+\mathrm{HCO}_{3}{ }^{-}\right)-\left(\mathrm{Ca}^{2+}+\mathrm{Mg}^{2+}\right)$.

The concentration of ions is expressed in meq/L. According to the US Department of Agriculture, water having more than $2.50 \mathrm{meq} / \mathrm{L}$ of RSC is not suitable for irrigation purposes. Based on the RSC values $91.11 \%$ of groundwater samples fall under good category and remaining $8.82 \%$ fall under doubtful category (Table 4).

\section{Magnesium hazard (MH)}

Generally, calcium and magnesium maintain a state of equilibrium in most waters. Calcium and magnesium do not behave equally in the soil system; magnesium deteriorates soil structure particularly when water is sodium dominated and highly saline. A high level of $\mathrm{Mg}^{2+}$ is usually due to the presence of exchangeable $\mathrm{Na}^{+}$in irrigated soils. In equilibrium, more $\mathrm{Mg}^{2+}$ present in water will adversely affect the soil quality, rendering it alkaline, resulting in decreased and adversely affected crop yields. Szabolcs and Darab (1964) proposed a magnesium hazard $(\mathrm{MH})$ value for irrigation water and an $\mathrm{MH}$ is calculated by the following equation.

Magnesium hazard $(\mathrm{MH})=\mathrm{Mg}^{2+} \times 100 /\left(\mathrm{Ca}^{2+}+\mathrm{Mg}^{2+}\right)$, where all ions are expressed in meq/L. A magnesium ratio of more than 50 is considered to be harmful and unsuitable for irrigation use. This would be adversely affecting the crop yield, as soils become more alkaline. The magnesium hazard values of the study area range from 0.48 to 76.73 with an average value of 32.06 (Table 4). Majority

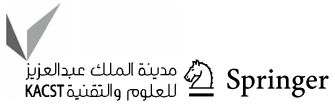


Fig. 6 Classification of irrigation water quality with respect to electrical conductivity and percent sodium (after Wilcox 1955)

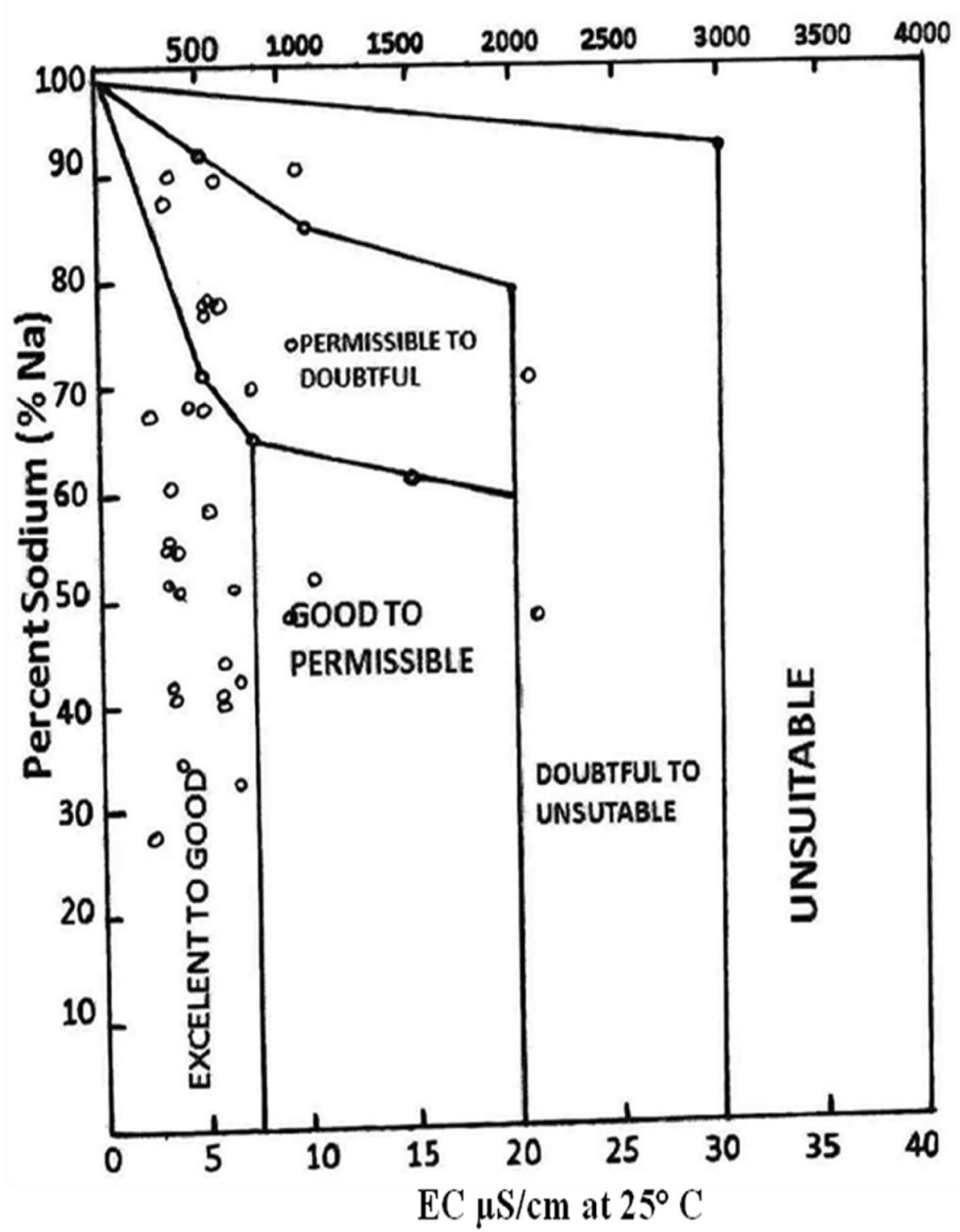

of groundwater samples $(88 \%)$ are within magnesium hazard of 50 and remaining $12 \%$ of groundwater samples were above 50 which are considered as harmful and unsuitable for irrigation use.

\section{Conclusions}

The main aim of this study was to evaluate the groundwater quality for irrigation and domestic application in Basara region, Adilabad district, South India. The entire study area occupied by Archaean crystalline rocks is represented by pink and gray granites. Groundwater in the Basara region is mostly alkaline in nature. The hydrochemical analysis data revealed that the highest nitrate was in the Bederelli village (80 mg/L), Aljapur, Vitholi thanda and near Basara
(60 mg/L), while high fluoride was at Karegaon village (4.33 mg/L), Mudhole (2.5 mg/L), Gannora and Bamanagon $(3.1 \mathrm{mg} / \mathrm{L})$, lowest at Bederelli village $(0.06 \mathrm{mg} / \mathrm{L})$. Calcium, sodium, magnesium and sulfate were within the permissible limit, but chloride is higher at Bederelli village $(1010 \mathrm{mg} / \mathrm{L})$. However, $59 \%$ and $56 \%$ of groundwater samples were shown $\mathrm{Na}^{+}-\mathrm{SO}_{4}{ }^{2-}$ and deep meteoric signatures respectively, which were typically influenced by the groundwater chemistry. The interesting and most significant finding of this study was that almost all groundwater samples were under-saturated with respect to Anhydrite, Aragonite, Artinite, Brucite, Calcite, Fluorite, Gypsum, Dolomite, Epsomite, Halite, Hydromagnesite, Lime, Mirabilite, Natron, Nesquehonite, Periclase, Portlandite, Thenardite, Thermonatrite, Vaterite and Magnesite. Based on Gibbs, groundwater samples from the Basara region show 
rock dominance indicating prevalent water-rock interaction through percolation is also wide and some of the samples are inclining towards evaporation. Most of the groundwater samples fall into the C2S1 dominance in US Salinity Laboratory diagram indicating medium salinity and low alkalinity water which is useful for irrigation in almost all types of soils. $\mathrm{Na} \%$, RSC and magnesium hazard reveal that in groundwater samples $59 \%$ belong to excellent to good category, $91.11 \%$ fall under good category and $88 \%$ are within magnesium hazard of 50 , which indicates its suitability for irrigation in all types of soils, respectively.

Acknowledgements The first author would like to extend sincere thanks to Dr. M. R. Kumar and Mr. A. Prasad for their constant encouragement and support in the field work and as well as analysis work. The author gratefully acknowledges the help and advice of the anonymous reviewer whose valuable comments helped improve the quality of this manuscript. Thanks are due to Enrico Driol, Editor-in-Chief, for his quick response, which helped to revise the manuscript periodically.

Open Access This article is distributed under the terms of the Creative Commons Attribution 4.0 International License (http://creativeco mmons.org/licenses/by/4.0/), which permits unrestricted use, distribution, and reproduction in any medium, provided you give appropriate credit to the original author(s) and the source, provide a link to the Creative Commons license, and indicate if changes were made.

\section{References}

Ackah M, Agyemang O, Anim AK, Osei J, Bentil NO, Kpattah L, Hanson JEK (2011) Assessment of groundwater quality for drinking and irrigation: the case study of Teiman-Oyarifa Community, Ga East Municipality, Ghana. Proceedings of the International Academy of Ecology and Environmental Sciences 1(3-4):186-194

Adimalla N, Venkatayogi S (2017) Mechanism of fluoride enrichment in groundwater of hard rock aquifers in Medak, Telangana State. South India. Environmental Earth Sciences 76(1):45. https://doi. org/10.1007/s12665-016-6362-2

Aghazadeh N, Mogaddam AA (2010) Assessment of groundwater quality and its suitability for drinking and agricultural uses in the Oshnavieh area, Northwest of Iran. J Environ Prot 1(01):30

APHA (1999) Standard methods for the examination of water and wastewater, 20th edn. American Public Health Association, Washington DC

Appelo CAJ, Postma D (1996) Geochemistry, groundwater and pollution. Balkema, Rotterdam, p 536

Bhardwaj V, Singh DS (2011) Surface and groundwater quality characterization of Deoria District, Ganga Plain, India. Environ Earth Sci 63:383-395

Chadha DK (1999) A proposed new diagram for geochemical classification of natural waters and interpretation of chemical data. Hydrogeol J 7:431-439

Chae GT, Yuna ST, Mayer B, Kima KH, Kim SY, Kwon JS, Kim K, Koh YK (2007) Fluorine geochemistry in bedrock groundwater of South Korea. Sci Total Environ 385:272-283

Deshmukh AN, Valadaskar PM, Malpe DB (1995) Fluoride in environment: a review. Gondwana Geol Mag 9:1-20

Deutsch WJ (1997) Groundwater geochemistry: fundamentals and application to contamination. CRC, Boca Raton
Ding H, Zhang J (2002) The problem of environmental caused by groundwater level continuous decline in the inland basins of arid area, Northwest China-an example in middle reaches of Heihe river basin (in Chinese). Hydrogeol Eng Geol 3:71-75

Dissanayake CB, Niwas JM, Weerasooriya SVR (1987) Heavy metal pollution of the mid canal of Kandis; An environmental case study from Sri Lanka. Environ Res 42:24-35

Eaton FM (1950) Significance of carbonates in irrigation waters. Soil Sci 39:123-133

Edmunds M, Smedley P (2005) Chapter 12: Fluoride in natural waters. In: Alloway B, Centeno JA, Finkleman RB, Fuge R, Lindh U, Smedley P, Selnius O (eds) Essentials of medical geology-impacts of the natural environment on public health. Academic Press, Amsterdam, pp 301-330

Elhatip H, Afsin M, Kuscu I, Dirik K, Kurmac Y, Kavurmac1 M (2003) Influences of human activities and agriculture on groundwater quality of Kayseri-Incesu-Dokuzpınar springs, Central Anatolian part of Turkey. Environ Geol 44:490-494

Frenkel H (1984) Reassessment of water quality criteria for irrigation. In: Shainberg I, Shalhevet J (eds) Soil salinity under irrigation. Process and management. Springer, Berlin, pp 298-318

Garg VK, Suthar S, Singh S, Sheoran A, Garima M, Jai S (2009) Drinking water quality in villages of southwestern Haryana, India: assessing human health risks associated with hydrochemistry. Environ Geol 58:1329-1340

Gibbs RJ (1970) Mechanisms controlling worlds water chemistry. Science 170:1088-1090

Gowd SS (2005) Assessment of groundwater quality for drinking and irrigation purposes: a case study of Peddavanka watershed, Anantapur District, Andhra Pradesh, India. Environ Geol 48(6):702-712

Guo F, Jiang G, Yuan D (2007) Major ions in typical subterranean rivers and their anthropogenic impacts in southwest karst areas, China. Environ Geol 53:533-541

Gustafsson GP (2012) Visual MINTEQ, ver 3.00. Royal Institute of Technology, Stockholm, Sweden, Department of Land and Water Resources Engineering. http://hem.bredband.net/ b108693S(Allison JD, Brown DS, Novo-Gradac KJ (1991) MINTEQA2)

Hem JD (1985) Study and interpretation of the chemical characteristics of natural water, 2nd edn. US Geol Surv Water Supply Paper 2254:363

Hem JD (1991) Study and interpretation of the chemical characteristics of natural water: USGS Professional Paper Book 2254. Scientific Publishers, Jodhpur

Islam J, Singhal N (2004) A laboratory study of landfill-leachate transport in soils. Water Res 38:2035-2042

Jain CK, Bandyopadhyay A, Bhadra A (2010) Assessment of ground water quality for drinking purpose, District Nainital, Uttarakhand, India. Environ Monit Assess 166(1-4):663-676

Kara EE, Pirlak U, Ozdilek G (2004) Evaluation of heavy metals $(\mathrm{Cd}, \mathrm{Cu}, \mathrm{Ni}, \mathrm{Pb}$, and $\mathrm{Zn})$ distribution in sowing regions of

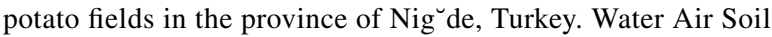
Pollut 153:173-186

Karanth KR (1989) Groundwater assessment, development and management. Tata McGraw-Hill Publ. Com. Ltd, New Delhi

Kinzelbach W, Bauer P, Siegfried T, Brunner P (2003) Sustainable groundwater management-problems and scientific tools. Episodes 26(4):279-284

Krishna AK, Govil PK (2004) Heavy metal contamination of soil around Pali Industrial Area, Rajasthan, India. Environ Geol $47: 38-44$

Kumar R, Singh RD, Sharma KD (2005) Water resources of India Curr Sci 89(5):794-811

Kumar M, Kumari K, Ramanathan AL, Saxena R (2007) A comparative evaluation of groundwater suitability for irrigation

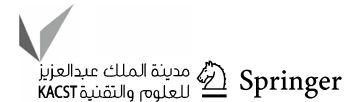


and drinking purposes in two intensively cultivated districts of Punjab, India. Environ Geol 53(3):553-574

Loizidou M, Kapetanios EG (1993) Effect of leachate from landfills on underground water quality. Sci Total Environ 128:69-81

McBride MB (2004) Molybdenum, sulfur, and other trace elements in farm soils and forages after sewage sludge application. Commun Soil Sci Plant Anal 35:517-535

Mikayilov FD, Acar B (1998) Toprak ekosistemlerinde kirleticilerin tas, $\_$ım mekanizmasının incelenmesi ve modellenmesi (Investigation and modelling of contaminant's movement processes within the soil ecosystems). C, ev Kor 28:20-23

Nagaraju A, Sunil Kumar K, Thejaswi A (2014) Assessment of groundwater quality for irrigation: a case study from Bandalamottu lead mining area, Guntur District, Andhra Pradesh, South India. Appl Water Sci 4:385-396

Narany TS, Ramli MF, Aris AZ, Sulaiman WNA, Fakharian K (2015) Groundwater irrigation quality mapping using geostatistical techniques in Amol-Babol Plain, Iran. Arab J Geosci 8(2):961-976

Narsimha A, Sudarshan V (2013) Hydrogeochemistry of groundwater in Basara area, Adilabad District, Andhra Pradesh. India. J Appl Geochem 15(2):224-237

Narsimha A, Sudarshan V (2017a) Contamination of fluoride in groundwater and its effect on human health: a case study in hard rock aquifers of Siddipet, Telangana State, India. Appl Water Sci 7:2501-2512. https://doi.org/10.1007/s13201-016-0441-0

Narsimha A, Sudarshan V (2017b) Assessment of fluoride contamination in groundwater from Basara, Adilabad District, Telangana State, India. Appl Water Sci 7:2717-2725. https://doi. org/10.1007/s13201-016-0489-x

Narsimha A, Sudarshan V, Swathi P (2013a) Groundwater and Its assessment for Irrigation purpose in Hanmakonda Area, Warangal District, Andhra Pradesh, India. Int J Res Chem Environ 3(2): 196-200

Narsimha A, Sudarshan V, Srinivasulu P, Anitha N, Parameshwar V (2013b) An integrated approach to assess the quality of groundwater in part of Cheralapally area, Rangareddy District, Andhra Pradesh, India. Adv Appl Sci Res 4(1):244-253

Nishanthiny SC, Thushyanthy M, Barathithasan T, Saravanan S (2010) Irrigation water quality based on hydro chemical analysis, Jaffna, Sri Lanka. Am Eur J Agric Environ Sci 7(1):100-102

Ragunath HM (1987) Groundwater. Wiley Eastern, New Delhi, p 563

Raju JN, Shukla UK, Ram Prahlad (2011) Hydrogeochemistry for the assessment of groundwater quality in Varanasi: a fast-urbanizing center in Uttar Pradesh, India. Environ Monit Assess 173:279-300

Ramesam V, Barua SK (1973) Preliminary studies on the mechanisms of controlling salinity in the North Western arid regions of India. Indian Geohydrol 9:10-18

Richards LA (1954) Diagnosis and improvement of saline and alkaline soils. Department of Agriculture Hand Book, US, p 60
Sawyer CN (1994) Chemistry. McGraw Hill, New York, pp 103-104

Sawyer CN, Mccarty PL, Parkin GF (2003) Chemistry for environmental engineering and science, 5th edn. McGraw-Hill, New York, p 752

Schilling KE, Wolter CF (2007) A GIS-based groundwater travel time model to evaluate stream nitrate concentration reductions from land use change. Environ Geol 53:433-443

Shand SJ (1952) Rocks for chemistry. Patmann Publishing Company, New York, p 146

Soltan ME (1999) Evaluation of groundwater quality in Dakhla Oasis (Egyptian Western Desert). Eviron Monit Assess 57:157-168

Subba Rao N, Krishna Rao G (1991) Groundwater quality in Visakhapatnam urban area, Andhra Pradesh. Indian J Environ Health 33(1):25-30

Subramani T, Elango L, Damodarasamy SR (2005) Groundwater quality and its suitability for drinking and agricultural use in Chithar River Basin, Tamil Nadu, India. Environ Geology 47(8):1099-1110

Szabolcs I, Darab C (1964) The influence of irrigation water of high sodium carbonate content of soils. In: Proceedings of 8th international congress of ISSS, Trans, vol II, pp 803-812

Todd DK (1980) Groundwater hydrology, 2nd edn. Wiley, New York, p 315

US Geological Survey (2000) Classification of natural ponds and lakes. US Department of the Interior, US Geological Survey, Washington, DC

US Salinity Laboratory Staff (1954) Diagnosis and improvement of saline and alkali soils. USDA handbook 60. US Government Printing Office, Washington, DC

Viswanathaiah MN, Sastri JCV, Rame Gowda B (1978) Mechanisms controlling the chemistry of ground waters of Karnataka. Indian Mineral 19:65-69

WHO (1990) Environmental health criteria 81: vanadium [R]. World Health Organization, Geneva, pp 1-35

WHO (2011) WHO Guidelines for Drinking-water Quality, fourth ed. World Health Organization

Wilcox LV (1955) Classification and use of irrigation waters. US Dept of Agricul Cir 969, Washington DC

Zhang B, Song X, Zhang Y, Han D, Tang C, Yu Y, Ma Y (2012) Hydrochemical characteristics and water quality assessment of surface water and groundwater in Songnen plain, Northeast China. Water Res 46(8):2737-2748

Publisher's Note Springer Nature remains neutral with regard to jurisdictional claims in published maps and institutional affiliations. 